\title{
PERBEDAAN BILANGAN PEROKSIDA PADA MINYAK JELANTAH SETELAH PENAMBAHAN BUBUK KULIT MANGGIS (Garcinia Mangostana Linn)
}

\author{
I Gusti Ayu Sri Dhyanaputri ${ }^{1}$, Cok Dewi Widhya Hana Sundari ${ }^{2}$ \\ ${ }^{1,2}$ Dosen Jurusan Analis Kesehatan Poltekkes Denpasar \\ puteridiana808@yahoo.co.id
}

\begin{abstract}
Damage to oil during the frying process caused by the oxidation process, it will affect the quality and nutritional value of the food that fried.The rate of oxidation of the oil can be inhibited by the addition of antioxidants. Antioxidants retard oxidation or free radicals from oxidized fats. As a natural antioxidant, mangosteen pericarp contains xanthones that are very effective in preventing the occurrence of free radicals. The problem in this study is whether there is a difference numbers peroxide in used cooking oils after addition of the mangosteen pericarp powdered? The purpose of research is to know the difference peroxide used cooking oil after the addition of the mangosteen pericarp powdered. This type of research is True Exsperiment Design by Design Post Test Only with Control Design. The treatments were the addition of the mangosteen pericarp powdered in some concentration : $0.10 \%, 0.20 \%, 0.30 \%, 0.40 \%$ and $0.50 \%$, and the soaking time mangosteen pericarp powder on used cooking oil during one day, two days and three days. The analysis was conducted using peroxide iodometri. Data analysis was conducted by using One Way Anova. followed by Least Significant Different (LSD). Data analysis showed a significant difference peroxide in used cooking oils after addition of mangosteen pericarp powder at various concentrations. The most effective concentration is $0.30 \%$, and the soaking time is one day.
\end{abstract}

Keywords: Numbers peroxide, mangosteen pericarp

\begin{abstract}
Abstrak. Kerusakan minyak selama proses penggorengan yang diakibatkan oleh proses oksidasi, akan mempengaruhi kualitas dan nilai gizi makanan yang digoreng. Laju oksidasi minyak dapat dihambat dengan penambahan antioksidan. Antioksidan menghambat oksidasi atau radikal bebas dari lemak teroksidasi. Sebagai antioksidan alami, bubuk kulit manggis mengandung xanthone yang sangat efektif dalam mencegah terbentuknya radikal bebas. Masalah dalam penelitian ini adalah apakah ada perbedaan jumlah peroksida pada minyak goreng bekas setelah penambahan bubuk kulit manggis? Penelitian ini bertujuan untuk mengetahui bilangan peroksida minyak jelantah setelah penambahan bubuk kulit manggis. Termasuk jenis penelitian True Exsperiment dengan Post Test Only with Control Design. Pemberian perlakuan penambahan bubuk kulit manggis dalam beberapa konsentrasi: $0,10 \%, 0,20 \%, 0,30 \%, 0,40 \%$ dan $0,50 \%$, dan waktu perendaman bubuk kulit manggis pada minyak goreng bekas selama satu hari, dua hari dan tiga hari. Analisis dilakukan dengan menggunakan Peroksida Iodometri. Analisis data dilakukan dengan menggunakan One Way Anova. diikuti oleh Least Significant Different (LSD). Hasil analisis data menunjukkan adanya perbedaan bilangan peroksida yang signifikan pada minyak goreng bekas setelah penambahan bubuk kulit manggis pada berbagai konsentrasi. Konsentrasi yang paling efektif adalah $0,30 \%$, dan waktu perendaman adalah satu hari.
\end{abstract}

Kata kunci: Bilangan peroksida, bubuk kulit manggis 


\section{Pendahuluan}

Kebiasaan menggunakan minyak goreng yang berulang, sering kita lihat di masyarakat terutama pada pedagang gorengan. Bahan makanan tersebut digoreng dalam minyak yang sudah berwarna cokelat kehitaman. Minyak goreng yang digunakan lebih dari empat kali dan bila dilihat dari kasat mata cenderung berwarna coklat tua sampai kehitaman disebut dengan minyak jelantah ${ }^{1}$. Penggunaan minyak jelantah ini dapat mengakibatkan perubahan fisik maupun kimia yang menyebakan penurunan kualitas dari bahan yang digoreng dan menyebabkan berbagai macam gangguan kesehatan,seperti pengendapan lemak dalam pembuluh darah (Artherosklerosis), serta kemungkinan adanya senyawa karsinogenik yang dapat mengakibatkan pertumbuhan kanker hati ${ }^{2}$. Selama penggorengan, minyak akan mengalami pemanasan pada suhu tinggi $\pm 170-180{ }^{\circ} \mathrm{C}$ dalam waktu yang cukup lama. Proses tersebut menyebabkan minyak mengalami kerusakan seperti :timbulnya bau dan rasa tengik, sedangkan kerusakan lain meliputi peningkatan kadar asam lemak bebas (FFA), perubahan indeks refraksi, bilangan peroksida, angka karbonil, timbulnya kekentalan minyak, terbentuknya busa dan adanya kotoran dari bumbu yang digunakan dan dari bahan yang digoreng $^{3}$.

Bilangan peroksida merupakan nilai terpenting untuk menentukan derajat kerusakan pada minyak. Apabila pada minyak terdapat bilangan peroksida yang tinggi maka kualitas dari minyak tersebut semakin buruk ${ }^{3}$. Berdasarkan standar mutu minyak goreng menurut SNI 3741-2013 yang mensyaratkan bilangan peroksida maksimal 10 mek $\mathrm{O}_{2} / \mathrm{kg}^{4}$. Laju oksidasi pada minyak dapat dihambat dengan penambahan antioksidan. Antioksidan akan menghambat oksidasi atau radikal bebas dari lemak yang teroksidasi. Sebagai salah satu antioksidan alami, kulit buah manggis diketahui mengandung senyawaxanthone yang sangat berkhasiat untuk mencegah terjadinya radikal bebas. Senyawa xanthone meliputi mangostin, mangostenol A, mangostinon A, mangostinon $B$, trapezifolixanthone, tovophyllin B, alfa mangostin, beta mangostin, garcinon B, mangostanol, flavonoid, epicatechin dan gartanin. Senyawa-senyawa tersebut sangat bermanfaat untuk mengikat radikal 
bebas, menghambat penuaan, dan mengontrol penyakit degeneratif seperti arthritis ${ }^{5}$.

Berdasarkan penelitian, penggunaan antioksidan alami (ekstrak etanol kulit buah manggis) lebih efektif menghambat proses oksidasi pada minyak krengseng dibandingkan dengan antioksidan sintetis Butylated hydroxytoluene (BHT). Selain itu, lama penyimpanan juga mempengaruhi besarnya bilangan peroksida, semakin lama penyimpanan maka semakin besar bilangan peroksidanya ${ }^{6}$. Penelitian pada kulit buah manggis yang diekstraksi menggunakan metode maserasi menggunakan pelarut methanol diperoleh ekstrak total sebanyak 2,3 g yang mempunyai aktivitas antioksidan $\pm 31,64 \%{ }^{7}$.

Perbedaan penelitian ini dengan penelitian sebelumnya adalah peneliti menggunakan bubuk kulit manggis secara langsung tanpa mengekstrak kulit manggis terlebih dahulu. Hal ini disebabkan karena peneliti ingin memanfaatkan limbah kulit manggis menjadi sesuatu yang lebih bermanfaat dan mudah diaplikasikan oleh masyarakat. Tujuan penelitian adalah untuk mengetahui bilangan peroksida minyak jelantah setelah penambahan bubuk kulit manggis.

\section{Metoda}

Jenis penelitian ini termasuk True Exsperiment Design karena dalam desain ini, peneliti melakukan intervensi dan mengontrol semua variabel luar yang mempengaruhi jalannya eksperimen.Desain penelitian yang digunakan yaitu Post Test Only with Control Design. Dalam desain ini terdapat dua kelompok,kelompok pertama diberi perlakuan (X) dan kelompok lain tidak. Kelompok yang diberi perlakuan disebut kelompok eksperimen dan kelompok yang tidak diberi perlakuan disebut kelompok kontrol $^{8}$. Unit analisis dalam penelitian ini adalah bilangan peroksida pada minyak jelantah dengan perlakuan lima jenis prosentase bubuk kulit manggis yaitu $0,10 \%, 0,20 \%, 0,30 \%, 0,40 \%$ dan $0,50 \%$ yang disimpan selama satu hari, dua hari dan tiga hari. Replikasi dilakukan sebanyak tiga kali. Dengan demikian diperoleh jumlah sampel ditambah dengan kontrol adalah 54 sampel. Untuk menguji normalitas data digunakan uji Kolmogrov Smirnov dan dilanjutkan dengan One 
Way Anova untuk melihat perbedaan yang ada pada setiap hasil perlakukan

\section{Hasil dan Pembahasan}

Buah manggis yang digunakan sebagai bahan baku dalam penelitian ini, diberi perlakuan awal yang meliputi pemisahan kulit manggis bagian dalam, pengeringan dengan oven sampai kadar air $\pm 8-10 \%$ dan pengecilan ukuran dengan menggunakan blender dan diayak dengan ayakan 80 mesh $^{9}$. Kulit manggis diukur kadar airnya dengan metode pemanasan langsung menggunakan oven pada suhu $50^{\circ} \mathrm{C}$. Hasil pemeriksaan kadar air dari bubuk kulit manggis seperti berikut:

Tabel 1. Kadar Air Kulit Manggis

\begin{tabular}{cc}
\hline Replikasi & Kadar Air $(\% \mathrm{bb})$ \\
\hline I & 9,32 \\
II & 8,67 \\
III & 8,92 \\
\hline Rata-rata & $8,97 \pm 0,27$
\end{tabular}

Rata-rata kadar air pada kulit manggis diperoleh $8,97 \pm 0,27$, hasil ini menunjukkan bahwa kadar air sudah cukup baik untuk dipakai sebagai bahan dalam pembuatan bubuk kulit manggis yang akan digunakan pada minyak jelantah. Uji organoleptik yang dilakukan meliputi pemeriksaan aroma dan warna dari sampel minyak jelantah yang akan diteliti tersebut. Hasil uji organoleptik dapat dilihat pada tabel 2 sebagai berikut :

Tabel 2. Hasil Uji Organoleptik Minyak Jelantah Setelah Penambahan Bubuk Kulit Manggis

\begin{tabular}{cccl}
\hline $\begin{array}{l}\text { Konsentrasi Penambahan } \\
\text { Bubuk Kulit Manggis }\end{array}$ & \multicolumn{2}{c}{ Parameter Uji Organoleptik } \\
\hline & Warna & \\
\hline $0 \%$ (control) & Coklat kehitaman & Seperti & gorengan \\
$0,1 \%$ & Kuning kecoklatan & Seperti & gorengan \\
$0,2 \%$ & Kuning kecoklatan & Seperti & gorengan \\
$0,3 \%$ & Kuning kecoklatan & Seperti & gorengan \\
$0,4 \%$ & Coklat kemerahan & Seperti & gorengan \\
$0,5 \%$ & Coklat kemerahan & Seperti & gorengan \\
\hline
\end{tabular}


Hasil uji organoleptik yang dilakukan pada sampel minyak jelantah tanpa diberikan perlakuan penambahan bubuk kulit manggis (kontrol) menunjukkan hasil yaitu memilki warna coklat kehitaman dan berbau khas seperti gorengan. Pada minyak jelantah yang diberikan perlakuan penambahan bubuk kulit manggis dengan konsentrasi $0,10 \%$, $0,20 \%$ dan $0,30 \%$ menunjukkan perubahan warna menjadi kuning kecoklatan dan berbau khas seperti gorengan. Sedangkan pada minyak jelantah yang diberikan perlakuan penambahan bubuk kulit manggis dengan konsentrasi $0,40 \%$ dan $0,50 \%$ terjadi perubahan warna yaitu menjadi coklat kemerahan dan memiliki bau khas seperti gorengan.

$$
\text { Pemeriksaan bilangan }
$$

peroksida pada sampel minyak jelantah setelah penambahan bubuk kulit manggis dengan metode iodometri bertujuan untuk mengetahui perbedaan bilangan peroksida setelah penambahan bubuk kulit manggis dengan berbagai konsentrasi dan perbedaan lama perendaman. Pengujian dilakukan dengan tiga kali replikasi. Hasil ratarata pemeriksaan bilangan peroksida pada sampel minyak jelantah dapat dilihat pada tabel 3:

Tabel 3. Hasil Rata-Rata Pemeriksaan Bilangan Peroksida Minyak Jelantah Setelah Penambahan Bubuk Kulit Manggis Pada Hari Perendaman Berbeda

\begin{tabular}{|c|c|c|c|}
\hline \multirow{2}{*}{$\begin{array}{c}\text { Konsentrasi } \\
\text { bubuk kulit } \\
\text { manggis }\end{array}$} & \multicolumn{3}{|c|}{$\begin{array}{c}\text { Rata-rata Bilangan Peroksida (meq O2/kg) } \pm \mathrm{SD} \\
\text { berdasarkan Lama Perendaman }\end{array}$} \\
\hline & 1 hari & 2 hari & 3 hari \\
\hline $0 \%$ (kontrol) & $11.75 \pm 1.28$ & $13.19 \pm 1.10$ & $16.02 \pm 1.44$ \\
\hline $0,1 \%$ & $9.48 \pm 0.32$ & $8.36 \pm 0.22$ & $8.74 \pm 0.17$ \\
\hline $0,2 \%$ & $8.16 \pm 0.62$ & $6.91 \pm 0.60$ & $7.63 \pm 0.85$ \\
\hline $0,3 \%$ & $7.16 \pm 0.20$ & $5.85 \pm 0.36$ & $6.32 \pm 0.56$ \\
\hline $0,4 \%$ & $6.20 \pm 0.36$ & $5.06 \pm 0.47$ & $5.68 \pm 0.43$ \\
\hline $0,5 \%$ & $6.24 \pm 0.22$ & $5.37 \pm 0.13$ & $5.78 \pm 0.17$ \\
\hline
\end{tabular}

Rata-rata bilangan peroksida tertinggi diperoleh pada control hari ketiga yaitu $16.02 \mathrm{meq} \quad \mathrm{O} 2 / \mathrm{kg}$ dengan standar deviasi \pm 1.44. Sedangkan rata-rata bilangan peroksida terendah diperoleh pada konsentrasi bubuk kulit manggis $0,4 \%$ pada hari ke dua yaitu $5.06 \mathrm{meqO} / \mathrm{kg}$ dengan standar deviasi \pm 0.47 
Hasil pemeriksaan bilangan peroksida pada minyak jelantah yang ditambahkan bubuk kulit manggis dengan berbagai konsentrasi pada hari pertama, kedua dan ketiga perendaman juga dapat dilihat pada gambar

berikut

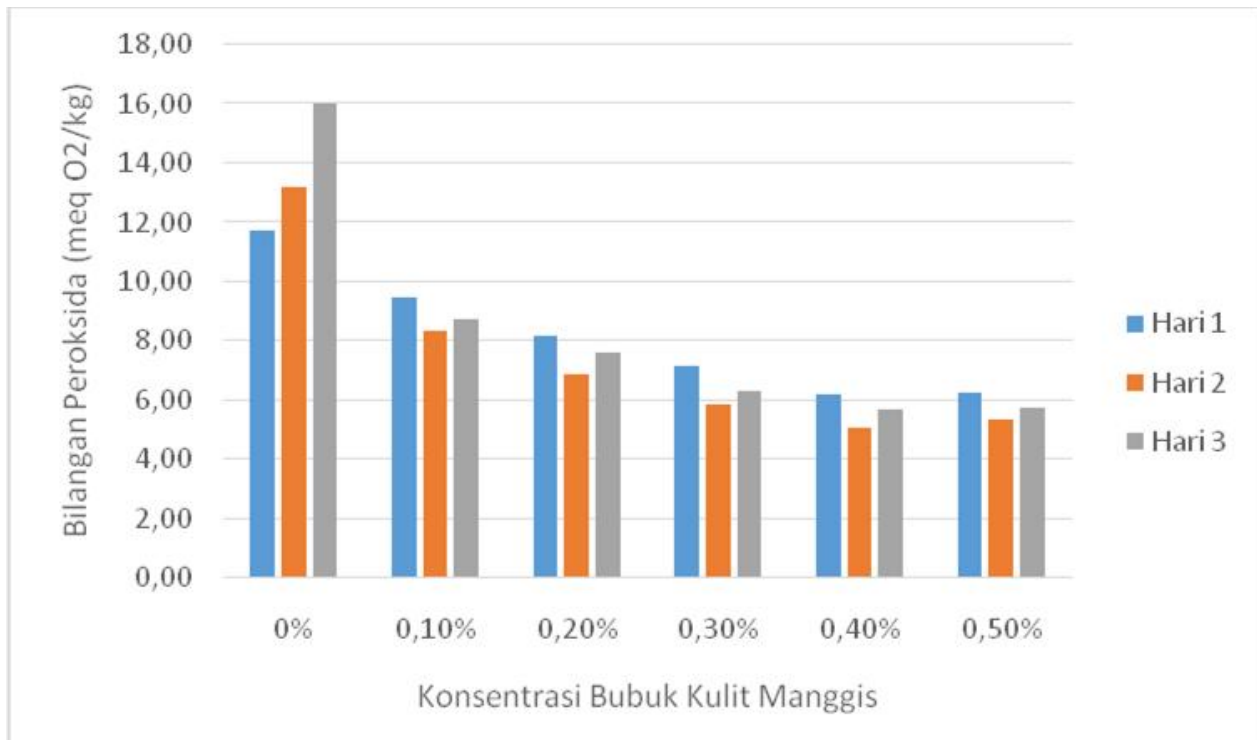

\section{Gambar 1}

Perbedaan Bilangan Peroksida Minyak Jelantah Pasca Penambahan Bubuk Kulit Manggis Dengan Berbagai Konsentrasi pada Perendaman Hari 1, 2 dan 3

Gambar 1. Menunjukkan bahwa pada kontrol, yaitu sampel minyak jelantah yang tidak ditambahkan bubuk kulit manggis terjadi peningkatan bilangan peroksida dari hari pertama ke hari kedua, dan terus meningkat pada hari ketiga. Sedangkan pada sampel minyak jelantah yang ditambahkan bubuk kulit manggis terjadi penurunan bilangan bilangan peroksida baik pada hari pertama, kedua maupun hari ketiga.
Hasil pemeriksaan bilangan peroksida di analisis menggunakan statistik. Normalitas data diuji dengan uji Kolmogorv-Smirnov. Berdasarkan uji normalitas data ini diperoleh hasil bahwa data berdidtribusi normal, yang ditunjukkan dengan nilai sig. = 0,117. Karena data berdistribusi normal maka analisis perbedaan bilangan peroksida pada minyak jelantah setelah penambahan bubuk kulit manggis dilakukan dengan uji one way anova. Hasil uji anova 
menunjukkan nilai $\mathrm{P}$ adalah 0,000 .

Karena nilai $\mathrm{P}$ lebih kecil dari $\alpha$ $(0,05)$ maka hipotesis nol ditolak. Jadi berdasarkan uji one way anova dapat dikatakan terdapat perbedaan bilangan peroksida pada minyak jelantah setelah penambahan bubuk kulit manggis. Hasil uji one way anova pada perbedan waktu hari perendaman dipreoleh nilai $\mathrm{P}=0,640$ jadi lebih besar dari $\alpha(0,05)$, hal ini menunjukkan tidak terdapat perbedaan bilangan peroksida yang signifikan pada perendaman hari pertama, kedua maupun har ketiga. Karena terdapat perbedaan bilangan peroksida pada minyak jelantah setelah penambahan bubuk kulit manggis dengan berbagai konsentrasi, maka uji dilanjutkan dengan uji LSD untuk melihat perbedaan antar berbagai konsentrasi penambahan bubuk kulit manggis. Hasil uji LSD menunjukkan bahwa terdapat perbedaan bilangan peroksida minyak jelantah yang singnifikan pada konsentrasi $0,1 \%, 0,2 \%$ dan $0,3 \%$ tapi tidak terdapat perbedaan yang signifikan pada konsentrasi $0,4 \%$ dan $0,5 \%$.

\section{Pembahasan}

Kulit manggis mengandung sejumlah pigmen yang berasal dari dua metabolit, yaitu alpha mangostin dan $\beta$ - mangostin yang merupakan bahan pewarna alami berupa antosianin yang menghasilkan warna merah, ungu dan biru. Oleh sebab itu, pada penambahan bubuk kulit manggis dengan konsentrasi yang cukup banyak menyebabkan minyak jelantah mengalami perubahan warna menjadi coklat kemerahan ${ }^{5}$.

Fungsi paling efektif dari antioksidan adalah dengan menghentikan reaksi berantai radikalradikal bebas (primary antioxidant ${ }^{10}$. Secara umum kandungan kimia yang terdapat dalam kulit manggis adalah xanthone, mangostin, garsinon, flavonoid dan tannin. Senyawa antioksidan terkuat pada kulit manggis adalah senyawa xanthone, disamping mempunyai kemampuan sebagai antioksidan senyawa xanthone juga sebagai antibakteri, antifungi, anti inflamasi, bahkan dapat menghambat petubuhan bakteri mycobacterium tubercholosis ${ }^{11}$. Senyawa xanthone merupakan substansi kimia alami yang dapat digolongkan dalam senyawa jenis fenol atau polyphenolic. Karena itulah 
senyawa xanthone dapat digolongkan sebagai senyawa jenis polar.

Pada sampel minyak jelantah tanpa perlakuan (kontrol) didapatkan rata-rata bilangan peroksida yaitu 11,75 meq $\mathrm{O}_{2} / \mathrm{kg}$ pada hari pertama, 13,19 meq $\mathrm{O}_{2} / \mathrm{kg}$ ada hari kedua dan 16,02 meq $\mathrm{O}_{2} / \mathrm{kg}$ pada hari ketiga. Hasil ini menunjukkan bilangan peroksida pada sampel minyak jelantah sudah melebihi batas standar SNI 3741-2013 karena batas standar maksimal bilangan peroksida $10 \mathrm{meq}$ $\mathrm{O}_{2} / \mathrm{kg}$. Meningkatnya bilangan peroksida pada kontrol dari hari pertama sampai hari ketiga menandakan bahwa reaksi oksidasi terus terjadi selama penyimpanan. Reaksi oksidasi berantai menyebabkan semakin lama reaksi berlangsung semakin cepat sehingga peningkatan bilangan peroksida juga semakin tinggi. Setelah penambahan bubuk kulit manggis, pada semua konsentrasi kadar bilangan peroksida di bawah standar SNI 3741-2013 karena batas standar maksimal bilangan peroksida $10 \mathrm{meq} \mathrm{O}_{2} / \mathrm{kg}$.

Hasil penelitian yang dilakukan pada penambahan bubuk kulit manggis dengan berbagai konsentrasi didapatkan terjadi penurunan bilangan peroksida pada semua konsentrasi bubuk kulit manggis dan semakin besar konsentrasi semakin besar penurunan bilangan peroksida pada minyak jelantah. Terdapatnya perbedaan bilangan peroksida pada minyak jelantah setelah penambahan bubuk kulit manggis juga ditunjukkan oleh hasil uji one way anova dimana nilai signifikansi yaitu 0,000 lebih kecil daripada $\alpha(0,05)$. Berasarkan uji LSD yang dilakukan, perbedaan bilangan peroksida yang signifikan terdapat pada konsentrasi $0,10 \%$, $0,20 \%$ dan $0,30 \%$, sedangkan pada konsentrasi $0,40 \%$ dan $0,50 \%$ tidak terdapat perbedaan yang signifikan. Hal ini disebabkan karena nilai perbedaan bilangan peroksida terlalu kecil sehingga pada saat dilakukan uji statistik tidak terdapat perbedaan yang signifikan. Sehingga konsentrasi bubuk kulit manggis yang paling efektif dalam menurunkan bilangan peroksida adalah konsentrasi $0,30 \%$.

Berdasarkan lama hari perendaman bubuk kulit manggis, tidak terdapat perbedaan bilangan peroksida yang bermakna karena nilai signifikansi 0,640 lebih besar dari $\alpha$ $(0,05)$. Hal ini disebabkan, walaupun terjadi penurunan bilangan peroksida 
dari hari pertama, kedua dan ketiga, tetapi penurunannya sedikit atau tidak bermakna secara statistic. Sehingga perendaman satu hari saja yang paling efekif dalam menurunkan bilangan peroksida pada minyak jelantah. Prosentase penurunan bilangan peroksida yang tertinggi terdapat pada perendaman hari ketiga, hal ini disebabkan karena kadar bilangan peroksida pada kotrol terus meningkat setiap hari sedangkan minyak jelantah yang diberikan bubuk kulit manggis tidak terjadi peningkatan bilangan perosida.

\section{Simpulan dan Saran}

Terdapat perbedaan bermakna bilangan peroksida pada minyak jelantah setelah penambahan bubuk kulit manggis. Konsentrasi penambahan bubuk kulit manggis

\section{Daftar Pustaka}

1. Mulasari, S. A. dan R. R. Utami, Kandungan Peroksida Pada Minyak Goreng di Pedagang Gorengan Sepanjang Jalan Prof. Soepomo Umbulharjo Yogyakarta, (online), available : ojs.unud.ac.id/index.php/ ach/article/ download/8735/6478, 2012, (7 Maret 2015).

2. Wijana, S., Nur H. dan Arif H., Mengolah Minyak Goreng Bekas, Surabaya: Trubus Agrisarana.2005. pada minyak jelantah yang paling efektif menurunkan bilangan peroksida adalah konsentrasi $0,30 \%$. Lama perendaman bubuk kulit manggis pada minyak jelantah yang paling efektif menurunkan bilangan peroksida adalah sehari.

Bagi masyarakat disarankan agar tidak menggunakan minyak goreng lebih dari empat kali penggorengan dan mengganti minyak goreng yang sudah berwarna kecoklatan. Penggunaan minyak jelantah dapat mengakibatkan berbagai macam penyakit salah satunya adalah kanker. Bubuk kulit manggis dapat dimanfaatkan untuk memperbaiki kualitas bilangan peroksida minyak jelantah dengan menambahkannya sebanyak $0,30 \%$ dan direndam selama satu hari.

3. Ketaren, S., Minyak dan Lemak Pangan, Jakarta : UI Press. 2008.

4. Badan Standarisasi Nasional, SNI 374I -2013 : Minyak Goreng, Jakarta : BSN. 2013.

5. Mardiana, L., Ramuan \& Khasiat Kulit Manggis, Jakarta: Penebar Swadaya.2011.

6. Muslimah, U. dan A. Gunarti, Ekstrak Etanol Kulit Buah Manggis (Garcinia mangostana L.) Sebagai Antioksidan Alami Pada Minyak Krengseng, (online), available :http://semnasffua.com/.../ 
PROSIDING\% 202014p2130.pdf, 2014, (20 Pebruari 2015).

7. Yuliarto, F. A., Konsentrasi Ekstrak Metanol Kulit Manggis (Garcinia mangostana L.) Sebagai Antioksidan Pada Minyak Kelapa, (online), available :eprints.uny.ac.id/3619, 2010,(20 Pebruari 2015).

8. Sugiyono, Metodologi Penelitian Kuantitatif Kualitatif Dan $R$ \& $D$, Bandung: Alfabeta. 2014.

9. Miryanti, Y. I. P. A., Lanny S., Kurniawan B. dan Stephen I., Ekstraksi Antioksidan dari Buah Manggis (Garcinia mangostana L.),

(online), available:journal.unpar.ac.id/inde x.php/rekayasa/article/ download/116/10, 2011,(7 Maret 2015).

10. Belleville-Nabet, F., Zat Gizi Antioksidan Penangkal Senyawa Radikal Pangan Dalam Sistem Biologis, dalam Prosiding Senyawa Radikal dan Sistem Pangan:Reaksi Biomolekuler, Dampak Terhadap Kesehatan dan Penangkal, Bogor: CFNSIPB. 1996.

11. Heyne, K., Tumbuhan Berguna Indonesia, Jakarta:Yayasan Sarana Wahaja.1997. 